\title{
Sedimentation Coefficients of Yeast Ribosomes
}

\author{
By J. De Ley \\ Laboratory for Microbiology, Faculty of Sciences, State University, Ghent, Belgium
}

(Received 25 May 1964)

\begin{abstract}
SUMMARY
The corrected sedimentation coefficients, expressed as $\left(S_{20, \mathrm{w}}\right)_{0}$, of ribosomes from nine different yeasts, representing a wide taxonomic range, were found to be $51 \cdot 5 \pm 2 \cdot 4,68 \cdot 6 \pm 3.3$ and $86.7 \pm 2.9 \times 10^{-13}$ sec. Very small quantities of a faster (approximately $128 \times 10^{-13} \mathrm{sec}$.) and a slower particle were sometimes detected. Yeast ribosomes have thus sedimentation coefficients which are distinctly different from bacterial ribosomes.
\end{abstract}

\section{INTRODUCTION}

It appears that ribosomes are not the same in all groups of organisms; it is generally assumed that ribosomes from bacteria are smaller or lighter than those from other organisms. It was recently shown (De Ley, 1964) that the corrected sedimentation coefficients of ribosomes from a wide variety of bacteria are nearly identical and had the values of $29 \cdot 5,37 \cdot 5,56 \cdot 3,76.7$ and $110.5 \mathrm{~S}$ (Svedberg units). It seemed desirable to determine these constants for other micro-organisms, e.g. yeasts, under the same experimental conditions and with the same equipment. Since information on yeast ribosomes is limited to Saccharomyces cerevisiae, it was decided to extend observations to other yeasts, representing a wide taxonomic spectrum. Ribosomal particles in $S$. cerevisiae were discovered by Schachman, Pardee \& Stanier (1952). The sedimentation coefficient at infinite dilution $\left(s_{20, w}\right)_{0}$ was found to be $80 \times$ $10^{-13}$ sec. (Chao \& Schachman, 1956); a similar value was also reported by Bowen, Dagley, Sykes \& Wild (1961). In solutions poor in $\mathrm{Mg}$ and $\mathrm{Ca}$, the $80 \mathrm{~S}$ ribosome dissociated into 60 and $40 \mathrm{~S}$ particles (Chao, 1957); papain action led to a similar breakdown (Morgan, Greenspan \& Cunningham, 1963). Morgan (1962) reported values of $71,75,80$ and 82 for the $80 \mathrm{~S}$ ribosomes, 54, 56, 57 and 60 for the $60 \mathrm{~S}$ ribosomes and 33,36 and 39 for the $40 \mathrm{~S}$ ribosomes. A new particle, originating from the $60 \mathrm{~S}$ ribosome, and with a sedimentation coefficient of about $50 \mathrm{~S}$ was detected. Koehler (1962) reported the corrected values of about 120 S, 80-95 S, 58-66 S, 42-53 S and 20-32 S. Furthermore, Koehler's results allowed the conclusion that yeast ribosomes were smaller than bacterial ones, and not bigger as was generally assumed. Differences in the relative amounts of the ribosomes during changes in the physiological state of the yeast cells have been reported by Wolfe (1956), Ashikawa (1958) and Koehler (1962).

\section{METHODS}

Organisms and culture conditions. The strains used are mentioned in Table 1. With the exception of Saccharomyces cerevisiae Hansen which we isolated in pure culture from commercial baker's yeast, all the strains used were obtained through the 
courtesy of the Centraalbureau voor Schimmelkultures, Baarn, the Netherlands. Unless otherwise stated, these yeasts were grown in liquid unhopped malt-extract $\left(8^{\circ}\right.$ Balling; $\left.\mathrm{pH} 6\right)$. S. cerevisiae grew somewhat better in $(\%, \mathrm{w} / \mathrm{v}): 1 \cdot 5$, malt extract broth (Difco); 0.078, Bacto-peptone (Difco); 1.2, maltose; 0.2, glycerol; 0.1, $\mathrm{K}_{2} \mathrm{HPO}_{4} ; 0 \cdot 1, \mathrm{NH}_{4} \mathrm{Cl}$; final $\mathrm{pH} \mathrm{6.5}$. The organisms were grown in $200 \mathrm{ml}$. volumes of the medium in 1 l. Erlenmeyer flasks on a reciprocal shaker at $30^{\circ}$, except for Lipomyces lipoferus which was grown at room temperature $\left(18-\mathbf{2 3}^{\circ}\right)$ and Nadsonia fulvescens which was grown at $18^{\circ}$. After 1-2 days, young cultures in the exponential phase were harvested by centrifugation for $15 \mathrm{~min}$. at 12,000 $\mathrm{g}$. Another set of flasks, with the yeasts in the stationary phase, were harvested after 4-7 days. Before harvesting, all cultures were examined microscopically for contamination.

Preparation of cell-free extracts. The organisms were washed by centrifugation two to three times from TMS buffer ( $\mathrm{pH} 7 \cdot 1$; 0.01M-tris, 0.004M-succinic acid, 0.005M$\left.\mathrm{MgSO}_{4}\right)$; this buffer was used in all the work. To improve subsequent mechanical breakage, the paste of organisms was frozen overnight at $-20^{\circ}$, and then disrupted in the Hughes block (Shandon Scientific Co., London) by a few severe blows with the Denbigh Fly Press no. 4 (Th. Ward Ltd., Albion Works, Sheffield). The resulting mass was suspended in an equal volume of TMS buffer. After addition of a minute crystal of crystalline DNAase (Worthington, Freehold, N.J., U.S.A.), the suspension was left for $1 \mathrm{hr}$ at $22^{\circ}$ and then centrifuged at $12,000 \mathrm{~g}$ for $15 \mathrm{~min}$. at $4^{\circ}$ in a Servall RC2 Centrifuge (Ivan Servall Inc., Norwalk, Conn., U.S.A.) to eliminate unbroken organisms and large pieces of debris. The supernatant fluid was used at once for ultracentrifugal analysis.

Analytical ultracentrifugation was carried out exactly as described before (De Ley, 1964).

\section{RESULTS}

Corrections to be applied to experimental $S$ values. The same corrections were applied as described in the previous paper (De Ley, 1964). The effect of pressure and dilution was again found to be negligible. The effect of concentration was the most important one. From each crude extract dilutions of $3 / 4,1 / 2,1 / 4,1 / 8$ and sometimes $1 / 16$ in TMS buffer were made and the sedimentation coefficients determined. These values were extrapolated to infinite dilution and called $\left(s_{20, \text { rms }}\right)_{0}$. The difference between the experimental sedimentation coefficient $s_{\mathrm{o}}$ in the crude extract and the extrapolated value was in the range $12-42 \%$. As in the case of bacteria, where similar differences were observed, quite considerable errors can be introduced in the $S$ nomenclature of ribosomes when this correction is not taken into account.

The corrected sedimentation coefficients of yeast ribosomes. The results are collected in Table 1. Five types of ribosomes were seen; only three of them were present in sufficient amounts for measurement of their sedimentation coefficient with certainty. The average $\left(s_{20, \text { TMs }}\right)_{0}$ values, expressed as Svedberg units $(\mathbf{S})$, were calculated to be $49 \cdot 8 \pm \mathbf{2} \cdot 3,66 \cdot 4 \pm 3 \cdot 2$ and $83 \cdot 9 \pm \mathbf{2} \cdot 8$. Faster particles, with an average $S$ of 124 , occurred only in small amounts in some strains. Small particles of the order of $30 \mathrm{~S}$ were seen only rarely and in minute amount. According to our previous paper, the reduction to standard conditions was calculated with the formula $\left(s_{20 \mathrm{w}}\right)_{0}=1.035$ $\left(s_{20, \text { TMS }}\right)_{0}$. The reduced values are $51 \cdot 5 \pm 2 \cdot 4,68 \cdot 6 \pm 3 \cdot 3,86 \cdot 7 \pm 2 \cdot 9$ and about 128 .

Influence of the medium and its $\mathbf{M g}^{2+}$ concentration. It is known that the $\mathrm{Mg}^{2+}$ 
concentration of the medium affects the relative amounts of bacterial ribosomes. In a previous paper (De Ley, 1964) it was reported that their sedimentation coefficients were not noticeably influenced. A similar result was obtained with yeast ribosomes. The sedimentation coefficients of Saccharomyces ribosomes were determined both from organisms grown on the complex malt medium in the absence of added $\mathrm{Mg}^{2+}$ and from organisms grown on a defined glucose + salts + vitamin medium (Lodder \& Kreger-van Rij, 1952), containing 0.004M-MgSO ${ }_{4}$. There was no noticeable difference between the sedimentation coefficients observed.

Table 1. Corrected sedimentation coefficients, expressed as $\left(s_{20, \mathrm{Tws}}\right)_{0} \times 10^{13} \mathrm{sec}$, of ribosomal particles from several yeasts

Values in parentheses are from particles present in very small amount only in the highest concentration of crude extract examined. They could not be determined by extrapolation, but $s_{\mathrm{O}}$ versus $\left(s_{20,} \text { TMs }\right)_{0}$ plots according to De Ley (1964) were used. These values are only close approximations.

\begin{tabular}{|c|c|c|c|c|c|c|}
\hline \multirow{2}{*}{$\begin{array}{l}\text { Organism } \\
\text { Saccharomyces } \\
\text { cerevisiae Hansen }\end{array}$} & \multirow{2}{*}{$\begin{array}{l}\text { CBS* } \\
\text { no. } \\
\text { (Own } \\
\text { isolate) }\end{array}$} & \multirow{2}{*}{$\begin{array}{c}\text { Age } \\
\text { (days) } \\
1 \\
4\end{array}$} & \multicolumn{4}{|c|}{ Value of $\left(s_{20, \text { TMS }}\right)_{0} \times 10^{13} \mathrm{sec}$} \\
\hline & & & $\begin{array}{l}\text { None } \\
48 \cdot 9\end{array}$ & $\begin{array}{l}65 \cdot 1 \\
66 \cdot 3\end{array}$ & $\begin{array}{l}83 \cdot 6 \\
83 \cdot 2\end{array}$ & $\begin{array}{l}\text { None } \\
\text { (125) }\end{array}$ \\
\hline $\begin{array}{l}\text { Nematospora coryli } \\
\text { Peglion }\end{array}$ & 2608 & $\begin{array}{l}\mathbf{2} \\
\mathbf{5}\end{array}$ & $\begin{array}{l}51 \cdot 8 \\
54 \cdot 2\end{array}$ & $\begin{array}{l}68.5 \\
\text { None }\end{array}$ & $\begin{array}{l}85 \cdot 0 \\
86 \cdot 7\end{array}$ & $\begin{array}{l}(148) \\
(119)\end{array}$ \\
\hline $\begin{array}{l}\text { Sporobolomyces } \\
\text { salmonicolor } \\
\text { (Fischer et Brebeck) } \\
\text { Kluyver et van Niel }\end{array}$ & 490 & $\mathbf{2}$ & $\begin{array}{l}(\mathbf{5 1} \cdot 3) \\
\text { None }\end{array}$ & $\begin{array}{l}64 \cdot 3 \\
65 \cdot 9\end{array}$ & $\begin{array}{l}84 \cdot 1 \\
83 \cdot 7\end{array}$ & $\begin{array}{l}\text { (130) } \\
\text { None }\end{array}$ \\
\hline $\begin{array}{l}\text { Hansenula anomala } \\
\text { (Hansen) H. et P. } \\
\text { Sydow }\end{array}$ & 110 & $\begin{array}{l}2 \\
4\end{array}$ & $\begin{array}{l}(47 \cdot 3) \\
50 \cdot 6\end{array}$ & $\begin{array}{l}65 \cdot 9 \\
\text { None }\end{array}$ & $\begin{array}{l}83 \cdot 3 \\
84 \cdot 2\end{array}$ & $\begin{array}{l}\text { None } \\
\text { None }\end{array}$ \\
\hline $\begin{array}{l}\text { Cryptococcus laurentii } \\
\text { (Kufferath) Skinner }\end{array}$ & 139 & $\begin{array}{l}2 \\
4\end{array}$ & $\begin{array}{l}\text { None } \\
\text { None }\end{array}$ & $\begin{array}{c}67 \cdot 5 \\
(67 \cdot 3)\end{array}$ & $\begin{array}{l}83 \cdot 4 \\
84 \cdot 0\end{array}$ & $\begin{array}{l}\text { (117) } \\
\text { None }\end{array}$ \\
\hline $\begin{array}{l}\text { Nadsonia fulvescens } \\
\text { (Nadson et } \\
\text { Konokotina) Sydow }\end{array}$ & 2596 & 2 & $48 \cdot 8$ & $69 \cdot 6$ & $83 \cdot 3$ & (127) \\
\hline $\begin{array}{l}\text { Lipomyces lipoferus } \\
\text { (den Dooren de Jong) } \\
\text { Lodder et van Rij }\end{array}$ & g) & 2 & None & None & $83 \cdot 5$ & None \\
\hline $\begin{array}{l}\text { Schizosaccharomyces } \\
\text { pombe Lindner }\end{array}$ & 356 & $\mathbf{3}$ & None & $(70 \cdot 2)$ & $(87 \cdot 5)$ & (125) \\
\hline $\begin{array}{l}\text { Endomycopsis } \\
\text { capsularis } \\
\text { (Schiönning) Dekker }\end{array}$ & 2519 & $\begin{array}{l}2 \\
7\end{array}$ & $\begin{array}{l}(51 \cdot 5) \\
\text { None }\end{array}$ & $\begin{array}{l}\text { None } \\
\text { None }\end{array}$ & $\begin{array}{l}83 \cdot 8 \\
83 \cdot 6\end{array}$ & $\begin{array}{l}\text { None } \\
\text { None }\end{array}$ \\
\hline
\end{tabular}

* CBS = Centraalbureau voor Schimmelkultures, Baarn.

Influence of age of organisms. It is known that the physiological age of the organisms changes the relative amounts of ribosomal types (see Introduction). This was confirmed in the present work but not further examined. Table 1 shows that the sedimentation coefficients of ribosomes from young and old organisms were not noticeably different.

Dissociation of yeast ribosomes. Chao (1957) reported that the $80 \mathrm{~S}$ ribosomes of Saccharomyces dissociated into 60 and $40 \mathrm{~S}$ particles in conditions of $\mathrm{Mg}^{2+}$ or $\mathrm{Ca}^{2+}$ deficiency. We confirmed this with several types of yeasts. Decreasing the $\mathbf{M g}^{2+}$ 
concentration in the tris + succinate buffer from $0.015 \mathrm{M}$ to 0.005 and $0.0005 \mathrm{M}$; resulted in a decrease of our $86 \mathrm{~S}$ particles and a concomitant increase in the $51 \mathrm{~S}$ and $68 \mathrm{~S}$ particles. Increasing the $\mathrm{Mg}^{2+}$ concentration to $0.05 \mathrm{M}$ resulted in a decided decrease in the amount of the particles, possibly due to aggregation and very quick sedimentation.

\section{DISCUSSION}

Our corrected sedimentation coefficients are in good agreement with the values given by Koehler (1962). The ribosomes of the nine different yeasts examined appear to be identical or nearly identical. These organisms were selected as fairly representative yeasts in general. It thus seems likely that the ribosomes will be similar for all yeasts; if there are differences between different organisms, they fall within the experimental error. Yeast ribosomes have sedimentation coefficients which are distinctly different from bacterial ones.

The author is indebted to the Rockefeller Foundation, New York, U.S.A., for the gift of an analytical ultracentrifuge; to the Belgian Government for a research and personnel grant from the Collectief Fundamenteel Wetenschappelijk Onderzoek; to the Nationale Raad voor Wetenschapsbeleid for its aid; to the Centraalbureau voor Schimmelkultures, Baarn, Netherlands, for supplying the yeasts and to Techn. Eng. R. Tijtgat for skilful technical assistance.

\section{REFERENCES}

Ashikawa, J. K. (1958). Ultracentrifugal studies of microsomes from starving, nonproliferating and proliferating yeast. In Microsomal Particles and Protein Synthesis. Ed. by R. B. Roberts, p. 76. New York: Pergamon Press.

Bowen, J. T., Dagley, S., Sykes, J. \& Wimd, D. G. (1961). Nature of the ribosomes present in bacteria and yeast: a re-appraisal. Nature, Lond. 189, 638.

CHAO, F. (1957). Dissociation of macromolecular ribonucleoprotein of yeast. Arch. Biochem. 70, 426.

Chao, F. \& Schachman, H. K. (1956). The isolation and characterisation of a macromolecular ribonucleoprotein from yeast. Arch. Biochem. Biophys. 61, 220.

DE LEY, J. (1964). On the unity of bacterial ribosomes. J. gen. Microbiol. 34, 219.

KoemLer, J. K. (1962). Variation of yeast ribosomes with nutritional state. Nature, Lond. $194,757$.

Lodder, J. \& Kreger-Van RiJ, N. J. W. (1952). The Yeasts, p. 25. Amsterdam: North Holland Publishing Co.

Morgan, R. S. (1962). A new form of ribosome from yeast. J. mol. Biol. 4, 115.

Morgan, R. S., Greenspan, C. \& Cunningham, B. (1963). Dissociation of yeast ribosomes by papain. Biochim. biophys. Acta, 68, 642 .

Schachman, H. K., Pardee, A. B. \& Stanier, R. Y. (1952). Studies on macromolecular organization of microbial cells. Arch. Biochem. 38, 245.

WoLFE, R. G. (1956). Macromolecular constituents of proliferating and non-proliferating yeast extracts. Arch. Biochem. Biophys. 63, 100. 